\title{
Effects of protein sources on performance, carcass composition, blood parameters and meat quality in Charolais heifers
}

\author{
M. Ragni ${ }^{1}$, M.A. Colonna ${ }^{1 \#}$, A. Lestingi ${ }^{2}$, S. Tarricone $^{1}$, F. Giannico ${ }^{1}$, G. Marsico ${ }^{1}$ \& A.M. \\ Facciolongo ${ }^{3}$ \\ ${ }^{1}$ Department of Agricultural and Environmental Science, University of Bari Aldo Moro, Via G. Amendola 165/A, 70126, \\ Bari, Italy \\ ${ }^{2}$ Department of Veterinary Medicine, University of Bari Aldo Moro, Strada provinciale Casamassima, Km 3, 70010, \\ Valenzano (BA), Italy \\ ${ }^{3}$ Institute of Biosciences and Bioresources, National Research Council, Via G. Amendola 165/A, 70126, Bari, Italy
}

(Received 2 May 2018; Accepted 20 June 2018; First published online 8 August 2018)

\author{
Copyright resides with the authors in terms of the Creative Commons Attribution 4.0 South African Licence. \\ See: http://creativecommons.org/licenses/by/4.0/za \\ Condition of use: The user may copy, distribute, transmit and adapt the work, but must recognise the authors and the South African \\ Journal of Animal Science.
}

\begin{abstract}
The aim of the present study was to evaluate the effects of feeding faba bean and sweet lupin as alternative protein sources to soybean on productive performance, blood parameters, carcass composition, and chemical-physical characteristics of meat and its fatty acid (FA) profile in Charolais heifers. Twenty-four heifers were divided into three homogenous groups and fed with durum wheat straw and three iso-energetic and isonitrogenous pelleted complete diets containing $14 \%$ (on as-fed basis) soybean meal; $28 \%$ faba bean; and $20 \%$ sweet lupin seed. The animals were slaughtered after a 168 day feeding period, and the Longissimus lumborum muscle was sampled for meat quality measurements. The feed conversion index was better in the heifers fed faba bean compared with the soybean treatment group (6.71 versus 7.17). No differences were found among treatment groups in productive performance, slaughtering data and physical features. The concentration of linoleic acid in the meat of the soybean group differed significantly from that in the lupin group (2.38 versus 2.11\%). Feeding lupin seed increased the concentrations of C20:3 n-6 (0.09\%) and C20:4 n-6 (0.20\%) in meat significantly, compared with the soya- and faba bean treatments $(0.06-0.07 \%$ and $0.12-0.13 \%$, respectively). No differences were found among groups for blood parameters, except for urea concentration, which was lower in the lupin group compared with the concentrations in the serum of heifers receiving the soya bean treatment $(31.29$ as opposed to $37.56 \mathrm{mg} / \mathrm{dL})$. In conclusion, since faba bean and lupin seed did not affect any of the parameters negatively, these legume grains can be included successfully as alternative protein sources in beef cattle diet.
\end{abstract}

Keywords: Faba bean, lupin seed, soybean, beef cattle, feeding

\#Corresponding author: mariaantonietta.colonna@uniba.it

\section{Introduction}

Plant proteins are still a major focus of the European Common Agricultural Policy (CAP) for 20142020. Particular attention is given to grain legume production in European agriculture to counter the chronic plant protein supply deficit in the region (Zander et al., 2016). Plant proteins are represented mainly by legume grains such as pea, faba bean, lupin, chick pea, and oleaginous crops and leguminous forages (Tufarelli et al., 2012a). Farmers may apply a rotation between decomposing crops and renewable ones and interrupt the over-grain supply. Crop rotation has multiple environmental benefits such as improvement of soil structure and fertility, reduction of synthetic fertilizers and agrochemicals, and prevention of abandon or depletion of land owing to cereal monoculture. These benefits have led the European Union (EU) to promote a so-called plant protein plan. However, this was left to the decision of member states and only a few countries adopted this opportunity. Italy adopted CAP 2014-2020 to encourage the production of proteoleaginous crops to reduce dependence on in plant protein supply on importations. Presently in Italy, 
about $90 \%$ of soybean is imported in order to satisfy the needs of the animal feed industry since this legume is the main protein source in animal diets in this country.

Protein requirements have been satisfied by using soybean in feed formulations for ruminant nutrition. However, approximately $70 \%$ of the world's soybean production still comes from genetically modified (GM) cultivars that are not suitable for organic animal husbandry, the only form of animal farming that has expanded (SINAB, 2017). Moreover, soybean is not grown in southern Italy, where farmers prefer to use local feed sources to reduce management costs. Given these reasons, the use of legume seeds that can be cultivated successfully in the Apulia region, such as faba bean and lupin, may provide a valuable and profitable alternative in ruminant nutrition.

Faba bean (Vicia faba var. minor) has a high protein (25-32\%) and starch (42\%) content (Yu et al., 2002; Tufarelli et al., 2012b), but also anti-nutritional factors such as aminopyrimidine, tannins and glycosides whereas the nitrogen fraction is very soluble and easily degradable in the rumen (Crépon et al., 2010).. This could affect its use in ruminant nutrition. Several studies have shown that faba bean-based diets do not affect productive performance (Ragni et al. 2007a) and meat quality negatively (Atti \& Mahouachi, 2009; Tarricone et al., 2009; Vicenti et al., 2009; Scerra et al., 2011).

In comparison with soybean, lupin (Lupinus albus L.) has a low neutral detergent fibre (NDF) content and a crude protein level of 35\% (Prandini et al., 2005). However, lupin contains a highly degradable protein fraction, anti-nutritional factors (Masoero et al., 2005; Rotger et al., 2006) and alkaloids that make seeds bitter, poorly palatable and even toxic for animals at high ingestion levels (El Maadoudi, 2006). These factors have limited the use of lupin in animal diets, though increasing interest has been given to cultivars of sweet lupin such as Lupinus albus L. var. Multitalia, which produce seeds with lower contents of alkaloids and antinutritional factors (Magalhães et al., 2017).

Certain blood parameters are important indicators of the animal's nutritional status, and may be useful in identifying metabolic imbalances and disorders (Pavlík et al., 2010). The energy balance, especially when negative, may be detected by the non-esterified fatty acid (NEFA) serum concentration and reflects the animal's status (Van Saun, 2000). Blood glucose level also gives an important indication of the animal's nutritional status, and the urea blood concentration allows the evaluation of its protein metabolism (Cabaraux et al., 2005). Although there are several reports on the effect of dietary legume seeds on blood parameters in dairy cows (Volpelli et al., 2010, 2012) and lambs (Facciolongo et al., 2014; Lestingi et al., 2015; 2016), little information is available on beef cattle.

Therefore, the objective of this study was to evaluate the effects of replacing soybean with sweet lupin seed or faba bean as alternative protein sources on productive performance, carcass characteristics, haematological traits and meat quality in Charolais heifers.

\section{Materials and Methods}

The study was carried out at a farm in Putignano (BA), Apulia region, southern Italy $\left(40^{\circ} 51^{\prime} \mathrm{N}\right.$ latitude, $17^{\circ} 07^{\prime} \mathrm{E}$ longitude), lasting for 168 days from January to June. All procedures involving animals were performed according to the Italian Government Guidelines (Directive 98/58/EC, received in Italy by D.L. 146).

Twenty-four Charolais heifers, nine months old ( \pm 7 days) with an average initial bodyweight (BW) of $318 \mathrm{~kg}( \pm 6 \mathrm{~kg})$ were divided into three groups of eight animals each, and were similar in BW and age. During the trial, the heifers were housed individually in pens $\left(4 \mathrm{~m}^{2}\right)$, all of which were equipped with a trough, manger and outdoor paddock without grass. To facilitate adaptation to the dietary treatments, the heifers were fed increasing amounts of the experimental diets for two weeks. The groups were assigned to one of three dietary treatments: Group S received a diet containing 14\% of soybean meal (as-fed basis); Group F a diet containing $28 \%$ of faba bean and Group L, $20 \%$ of lupin seed (Lupinus albus cv Multitalia). The three pelleted total mixed rations (Table 1) were formulated to be isonitrogenous and iso-energetic. The pelleted diets were balanced for PDIN (intestinal digestible protein nitrogen) and PDIE (intestinal digestible protein energy) values to meet the heifers' nutritional requirements (INRA, 1989).

Feed was offered daily in the morning at a rate of $110 \%$ of ad libitum intake, calculated by weekly weighing back of refusals. All animals received durum wheat straw (Triticum durum L.) ad libitum. Feed samples were taken monthly and stored at $-20^{\circ} \mathrm{C}$ pending analysis. Every day, after each feeding, the remaining straw and pellet feeds were weighed to determine the daily feed intake of each group. Individual BWs were recorded at the beginning of the trial (day 0) and after 168 days (before slaughtering). The average daily gain (ADG), average daily feed intake (ADFI) and feed conversion ratio (FCR) (kg food ingested daily/kg daily body growth) were calculated.

Samples of each experimental diet were ground in a hammer mill with a 1-mm screen and analysed in triplicate using the AOAC (2004) procedures: dry matter (DM) (method 934.01), ether extract (EE) (method 920.39), ash (method 942.05), crude protein (CP) (method 954.01), crude fibre (CF) (method 945.18), acid detergent fibre (ADF), acid detergent lignin (ADL) (method 973.18) and amylase-treated NDF (method 
2002.04). Starch was determined according to AOAC procedure (2004) (method 996.11). The protein values (protein digested in the small intestine allowed by the energy (PDIE) and protein digested in the small intestine allowed by the nitrogen (PDIN)) were estimated using the equations proposed by INRA (1988). Samples of each concentrate mixture were used for FA analysis according to the method described for meat FA profile. The results are shown in Table 1.

Table 1 Feed ingredients ( $\mathrm{g} / \mathrm{kg}$ as fed basis), chemical (\% dry matter basis) and FA composition (\% FA methyl esters) of the treatment diets containing soybean, faba bean and sweet lupin

\begin{tabular}{|c|c|c|c|}
\hline \multirow{2}{*}{ Parameter } & \multicolumn{3}{|c|}{ Diets } \\
\hline & Soybean & Faba bean & Sweet Lupin \\
\hline \multicolumn{4}{|c|}{ Ingredient composition (g/kg as-fed basis) } \\
\hline Corn & 286 & 236 & 310 \\
\hline Barley & 130 & 80 & 200 \\
\hline Wheat flour shorts & 150 & 140 & 70 \\
\hline Wheat bran & 100 & 60 & 70 \\
\hline Dehydrated sugar beet pulps & 110 & 100 & 80 \\
\hline Molasses & 20 & 20 & 20 \\
\hline Corn gluten meal & 20 & 40 & 20 \\
\hline Soybean oil & 14 & 14 & 0 \\
\hline Soybean meal $\left(43.4 \% \mathrm{CP}^{1}\right)$ & 140 & 0 & 0 \\
\hline Faba bean $(27.0 \% \mathrm{CP})$ & 0 & 280 & 0 \\
\hline Lupin (35.0\% CP) & 0 & 0 & 200 \\
\hline Vitamin mineral premix & 30 & 30 & 30 \\
\hline \multicolumn{4}{|l|}{ Chemical composition ( $\mathrm{DM}^{2}$ basis) } \\
\hline Moisture (\% as-fed) & 13.00 & 13.00 & 12.50 \\
\hline Crude protein (\%) & 18.33 & 18.32 & 18.30 \\
\hline Ether extract (\%) & 4.32 & 4.28 & 4.30 \\
\hline Crude fibre (\%) & 7.81 & 7.65 & 7.98 \\
\hline Ash (\%) & 5.99 & 6.24 & 5.95 \\
\hline $\operatorname{NDF}^{3}(\%)$ & 21.11 & 21.52 & 21.96 \\
\hline $\mathrm{ADF}^{4}(\%)$ & 8.63 & 8.48 & 9.07 \\
\hline $\mathrm{ADL}^{5}(\%)$ & 1.56 & 1.56 & 1.74 \\
\hline Starch & 33.60 & 36.53 & 35.58 \\
\hline $\operatorname{PDIN}^{6}(\mathrm{~g} / \mathrm{kg} \mathrm{DM})$ & 116.65 & 126.90 & 113.32 \\
\hline $\mathrm{PDIE}^{7}$ (g/kg DM) & 117.44 & 120.21 & 111.17 \\
\hline Meat forage units (n/kg DM) & 1.08 & 1.08 & 1.07 \\
\hline \multicolumn{4}{|c|}{ Fatty acid composition (\% fatty acid methyl esters) } \\
\hline C16:0 & 17.68 & 18.58 & 13.21 \\
\hline C18:0 & 2.78 & 3.01 & 2.66 \\
\hline C18:1c9 (n-9) & 23.69 & 24.05 & 32.70 \\
\hline $\mathrm{C} 18: 2 \mathrm{c} 9, \mathrm{t} 11(\mathrm{n}-6)$ & 51.59 & 50.29 & 46.18 \\
\hline $\mathrm{C} 18: 3 \mathrm{c} 6,9,12(\mathrm{n}-3)$ & 4.25 & 4.06 & 5.24 \\
\hline
\end{tabular}

\footnotetext{
${ }^{1} \mathrm{CP}$ : crude protein; ${ }^{2} \mathrm{DM}$ : dry matter; ${ }^{3} \mathrm{NDF}$ : neutral detergent fibre; ${ }^{4} \mathrm{ADF}$ : acid detergent fibre; ${ }^{5} \mathrm{ADL}$ : acid detergent lignin; ${ }^{6} \mathrm{PDIN}$ : protein digested in the small intestine allowed by the nitrogen; ${ }^{7} \mathrm{PDIE}$ : protein digested in the small intestine allowed by the energy
} 
At the end of the trial (day 168), blood samples were taken from the jugular vein of each animal using a vacutainer ${ }^{\circledR}$, to analyse energy (glucose and non-esterified fatty acids; NEFA) and protein (urea, total protein and their electrophoresis fractions) metabolism parameters. Blood samples were collected on the farm and centrifuged within $30 \mathrm{~min}$ at $3000 \mathrm{rpm} \times 15 \mathrm{~min}$. The serum was divided into aliquots, transported at $4{ }^{\circ} \mathrm{C}$ to the laboratory, and frozen at $-20^{\circ} \mathrm{C}$ until analyses were performed. Serum concentration of variables was assessed with Assel reagents and a SEAC photometer with interferential filters (Assel S.r.l., Guidonia, Rome, Italy). Serum protein electrophoresis was performed on agarose gel according to the Helena BioSciences Europe method.

After blood collection, the heifers were transported to the slaughterhouse, where they were weighed and slaughtered by exsanguination, according to veterinary police rules (D.P.R. 320/54) after fasting for 12 hours, with free access to water. The hot carcass, full skin, head, pluck and shank were weighed. The weight of the digestive contents (full-empty gastro-intestinal tract) was used to calculate the net cold dressing percentage (carcass weight after chilling/empty bodyweight). The carcasses were divided into two half sides, which were weighed immediately, and after refrigeration for 24 hours at $4{ }^{\circ} \mathrm{C}$. Three days after slaughter the left half-carcass was divided into quarters, anterior and posterior. The anterior quarter was dissected into proximal and distal thoracic limb, neck and steaks (from the 1st to the 6th vertebra), briskets (from the 1st to the 6th rib), steaks (from the 7th to the 13th vertebra) and briskets (from the 7th to the 13th rib). The posterior quarter was sectioned into lumbar region (loin and tenderloin), abdominal region, proximal and distal pelvic limb, tail, kidney and perirenal fat. The relative proportion of the meat cuts was calculated as percentage of the right half-carcass weight. Two sample cuts, lumbar region and pelvic limb, were separated and dissected into their tissue components, lean, fat and bone.

The $\mathrm{pH}$ was measured on the Longissimus lumborum $(\mathrm{LI})$ of the right half-carcass at the time of slaughter $\left(\mathrm{pH}_{0}\right)$ and after 24 hours of refrigeration at $4{ }^{\circ} \mathrm{C}\left(\mathrm{pH}_{24}\right)$, using a portable instrument (Hanna Instruments HI 9025, Woonsocket, RI) with an electrode (FC 230C, Hanna Instruments) and performing twopoint calibration ( $\mathrm{pH} 7.01$ and 4.01). Samples of the $\mathrm{LI}$ muscle were taken to evaluate meat quality characteristics. Meat colour $\left(L^{*}=\right.$ lightness; $a^{*}=$ redness; $b^{*}=$ yellowness) was assessed using a HunterLab MiniScanTM XE spectrophotometer (Model 4500/L, 45/0 LAV, $3.20 \mathrm{~cm}$ diameter aperture, $10^{\circ}$ standard observer, focusing at $25 \mathrm{~mm}$, illuminant D65/10, Hunter Associates Laboratory, Inc, Reston, Virginia, USA) by taking three readings for each sample. The instrument was normalized to a standard white tile, which was supplied with the instrument, before the analysis was performed $(Y=92.8 ; x=0.3162$, and $y=0.3322)$. The reflectance measurements were performed after the sample had been oxygenated in air for at least 30 minutes, to allow the measurements to become stable (Šicklep \& Čandek-Potokar, 2007).

Meat tenderness was assessed on raw and cooked $L I$ samples with the Warner Bratzler shear (WBS) force system using an Instron 5544 Universal Testing Machine (Instron Corp., Canton, MA, USA). The samples had a cylindrical form of one inch $(25.4 \mathrm{~mm})$ diameter, and were assessed in triplicate and sheared perpendicularly to the muscle fibre direction (load cell $50 \mathrm{~kg}$, shearing speed $200 \mathrm{~mm} / \mathrm{min}$ ). Peak force was expressed as $\mathrm{kg} / \mathrm{cm}^{2}$. To determine the cooking loss percentage, homogeneous samples (about $5 \mathrm{~cm}$ thick) were cut from the $\mathrm{LI}$ muscle and weighed before and after cooking in a ventilated electric oven at $165^{\circ} \mathrm{C}$, until an internal temperature of $75^{\circ} \mathrm{C}$ was reached in the core of the sample (ASPA, 1996), as recorded by a thermocouple (Hanna Instruments).

Chemical analysis and FA profile were performed on raw meat of the $L /$ muscle, using $250 \mathrm{~g}$ samples, devoid of external fat, epimysium and parts in which metmyoglobin was visible. AOAC (1995) procedures were used to assess moisture, crude fat, protein and ash. Total lipids were extracted from the homogenized $\mathrm{Ll}$ samples $(100 \mathrm{~g})$ according to the chloroform/methanol method described by Folch et al. (1957). FAs were methylated using $\mathrm{BF}_{3}$-methanol solution $(12 \% \mathrm{v} / \mathrm{v})$ (Christie, 1982). The FA profile was assessed with a Chrompack CP 9000 gas chromatograph, with a silicate glass capillary column ( $70 \%$ cyanopropyl polysilphenylene-siloxane BPX 70 of SGE Analytical Science, length $50 \mathrm{~m}$, internal diameter $0.22 \mathrm{~mm}$, film thickness $0.25 \mu \mathrm{m}$ ). The temperature programme was $135^{\circ} \mathrm{C}$ for $7 \mathrm{~min}$, followed by increases of $4{ }^{\circ} \mathrm{C}$ per minute to $210^{\circ} \mathrm{C}$.

The food risk factors of meat were determined by calculating the atherogenic ( $\mathrm{Al}$ ) and thrombogenic (TI) indices (Ulbricht \& Southgate, 1991) as follows:

$$
\begin{aligned}
& \mathrm{Al}=\left[\left(\mathrm{C}_{12: 0}+4 \times \mathrm{C}_{14: 0}+\mathrm{C}_{16: 0}\right)\right] \div[\Sigma \mathrm{MUFA}+\Sigma \mathrm{n}-6+\Sigma \mathrm{n}-3] \\
& \mathrm{TI}=\left[\left(\mathrm{C}_{14: 0}+\mathrm{C}_{16: 0}+\mathrm{C}_{18: 0}\right)\right] \div[(0.5 \times \Sigma \text { MUFA }+0.5 \times \Sigma \mathrm{n}-6+3 \times \Sigma \mathrm{n}-3+\Sigma \mathrm{n}-3) / \Sigma \mathrm{n}-6]
\end{aligned}
$$

where MUFA are monounsaturated fatty acids. FAs were expressed as percentage (wt/wt) of total methylated FA.

Data were analysed for variance (ANOVA) using the GLM procedure of statistical software application (SAS, 2000). One-way ANOVA was used to analyse data and the main effect that was tested was dietary 
treatment. Results are reported as least squares means and pooled SED values. Means were compared with the Student's $t$-test.

\section{Results and Discussion}

Growth performances are presented in Table 2.

Table 2 Mean ( \pm SE) productive performances, average daily feed intake and feed conversion ratio of Charolais heifers

\begin{tabular}{|c|c|c|c|c|}
\hline & \multicolumn{3}{|c|}{ Diets } & \multirow{2}{*}{ SEM $^{1}$} \\
\hline & Soybean & Faba bean & Sweet Lupin & \\
\hline Initial bodyweight (kg) & 309.0 & 327.1 & 318.0 & 39.93 \\
\hline Slaughter bodyweight (kg) & 512.0 & 525.0 & 500.8 & 60.00 \\
\hline Average daily gain (kg/d) & 1.208 & 1.177 & 1.087 & 0.119 \\
\hline Average daily feed intake (kg/d) & $8.60^{A}$ & 7.82 & $7.69^{\mathrm{B}}$ & 0.371 \\
\hline Feed conversion ratio $(\mathrm{kg} / \mathrm{kg})$ & $7.17^{\mathrm{a}}$ & $6.71^{b}$ & 7.15 & 0.848 \\
\hline
\end{tabular}

The experimental treatments did not differ $(P>0.05)$ in slaughter BW and ADG. The current results are in general agreement with studies carried out on Podolian cattle by Girolami et al. (2007), who tested faba bean compared with soybean, and by Vicenti et al. (2009), who studied the effects of replacing soybean with lupin seed. However, Cocca et al. (2005) observed higher $(P<0.05)$ ADGs in Podolian calves fed with soybean compared with faba bean. The soybean group showed a higher $(P<0.01)$ feed intake than the lupin group, in agreement with other studies carried out on Podolian cattle (Girolami et al., 2007) and Gentile di Puglia lambs (Lestingi et al., 2015; 2016). The lower feed intake associated with lupin feed may be because of the alkaloid content of this legume grain, which is responsible for the bitter taste, although this parameter was not measured in the current experiment. The variety of sweet lupin used in the present study was Multitalia, an old Italian sweet variety. Although other varieties of sweet lupin have been found to contain lower levels of alkaloids (Calabrò et al., 2014), this variety is cultivated widely in Apulia and is used for human and animal nutrition. The heifers receiving the faba bean showed a better FCR $(P<0.05)$ compared with soybean, as Vicenti et al. (2009) also found in young Podolian bulls.

The slaughtering data reported in Table 3 does not show statistical differences among groups. Comparable results were found by Vicenti et al. (2009), while Cocca et al. (2005) reported a higher incidence of pluck in Podolian cattle fed with faba bean.

Table 3 Mean ( \pm SE) slaughtering data (percentage on empty bodyweight) of Charolais heifers

\begin{tabular}{lcccc}
\hline & \multicolumn{3}{c}{ Diets } & \multirow{2}{*}{ SEM $^{\mathbf{1}}$} \\
\cline { 2 - 4 } & Soybean & Faba bean & Sweet Lupin & \\
\hline Empty bodyweight $(\mathrm{kg})$ & 466.36 & 477.61 & 456.44 & 48.077 \\
Gastro-intestinal content & 8.88 & 9.03 & 8.80 & 0.496 \\
Cold dressing percentage & 67.49 & 67.79 & 67.07 & 2.294 \\
Skin & 7.24 & 7.20 & 7.32 & 0.830 \\
Head & 4.12 & 4.13 & 4.24 & 0.460 \\
Pluck & 3.03 & 3.09 & 3.10 & 0.237 \\
Shank & 1.66 & 1.58 & 1.67 & 0.398 \\
\hline
\end{tabular}

${ }^{\mathrm{I}}$ Standard error of means 
Anatomical jointing data are shown in Table 4. The only significant difference was observed for the proximal and distal thoracic limb, which was lower $(P<0.05)$ in the heifers receiving lupin seed compared with those fed the faba bean diet. This result may depend on the lower feed intake in subjects fed with lupin, which was confirmed by the trend for the BW and half-side carcass weight.

Table 4 Mean $( \pm$ SE) section data on the left half-carcass weight of Charolais heifers (\%)

\begin{tabular}{lcccc}
\hline & \multicolumn{3}{c}{ Diets } & \multirow{2}{*}{ SEM $^{1}$} \\
\cline { 2 - 4 } & Soybean & Faba bean & Sweet Lupin & \\
\hline Left half carcass weight (kg) & 155.1 & 159.8 & 150.3 & 17.041 \\
Neck + steaks (1st-13th vertebra) & 20.73 & 21.00 & 20.32 & 1.053 \\
Briskets (1st-13th rib) & 17.24 & 16.89 & 18.03 & 1.211 \\
Proximal and distal thoracic limb & 14.34 & $14.54^{\mathrm{a}}$ & $13.84^{\mathrm{b}}$ & 0.546 \\
Lumbar region & 3.84 & 3.98 & 3.99 & 0.220 \\
Abdominal region & 4.97 & 5.10 & 5.33 & 0.474 \\
Tenderloin & 2.07 & 2.07 & 1.96 & 0.139 \\
Proximal and distal pelvic limb & 32.68 & 32.47 & 32.48 & 1.223 \\
Tail & 0.93 & 1.02 & 0.95 & 0.103 \\
Kidney & 0.29 & 0.30 & 0.31 & 0.039 \\
Perirenal fat & 2.74 & 2.73 & 2.78 & 0.760 \\
\hline
\end{tabular}

${ }^{1}$ Standard error of means

${ }^{\mathrm{a}, \mathrm{b}}$ Row means differ significantly at $P<0.05$

The anatomical dissection of the proximal and distal pelvic limb and lumbar region (Table 5) did not show significant differences among the groups. In Podolian bulls, Cocca et al. (2005) found a higher proportion of fat when feeding soybean compared with faba bean, while a study on lambs, Ragni et al. (2000) reported that the feeding of lupin versus soybean provided the proximal and distal pelvic limb with a higher proportion of lean and a lower one of fat.

Table 5 Mean $( \pm$ SE) dissection data of pelvic limb and lumbar region of Charolais heifers

\begin{tabular}{ccccc}
\hline & \multicolumn{3}{c}{ Diets } & \multirow{2}{*}{ SEM $^{\mathbf{1}}$} \\
\cline { 2 - 4 } & Soybean & Faba bean & Sweet Lupin & \\
\hline Proximal and distal pelvic limb (kg) & 51.61 & 51.14 & 48.04 & 4.694 \\
Lean (\% on weight) & 74.66 & 73.57 & 72.9 & 1.934 \\
Fat (\% on weight) & 10.65 & 10.98 & 11.39 & 1.593 \\
Bone (\% on weight) & 14.68 & 15.44 & 15.7 & 1.175 \\
Lumbar region (kg) & 6.15 & 6.31 & 5.97 & 0.884 \\
Lean (\% on weight) & 64.54 & 64.79 & 63.77 & 2.346 \\
Fat (\% on weight) & 13.34 & 12.92 & 13.76 & 1.925 \\
Bone (\% on weight) & 22.12 & 22.29 & 22.46 & 2.229 \\
\hline
\end{tabular}

${ }^{\mathrm{I}}$ Standard error of means

The $\mathrm{pH}$ values (Table 6) that were measured at slaughtering and after 24 hours of refrigeration, averaged within the normal $\mathrm{pH}$ range reported for beef cattle (Mach et al., 2008) and were comparable with the results of Cocca et al. (2005) and Vicenti et al. (2009), who used the same dietary protein sources. 
In the current study, $\mathrm{pH}_{24}$ ranged from 5.51 to 5.54 . Beef with a $\mathrm{pH}_{24}$ greater than 5.5 is thought to be the result of pre-slaughter glycogen depletion, which is caused by physical exhaustion and pre-slaughter stress of cattle (Immonen \& Puolanne, 2000; Immonen et al., 2000). Consequently, the muscle is unable to accumulate adequate lactic acid concentration (Kannan et al., 2002).

Table 6 Mean ( \pm SE) physical and chemical data of meat from Longissimus lumborum muscle of Charolais heifers

\begin{tabular}{lcccc}
\hline & \multicolumn{3}{c}{ Diets } & \multirow{2}{*}{ SEM $^{\mathbf{1}}$} \\
\cline { 2 - 4 } & Soybean & Faba bean & Sweet Lupin & \\
\hline $\mathrm{pH}_{0}$ & 6.42 & 6.67 & 6.56 & 0.302 \\
$\mathrm{pH}_{24}$ & 5.54 & 5.51 & 5.52 & 0.073 \\
$\mathrm{~L}^{*^{2}}$ & 39.72 & 40.32 & 40.87 & 3.057 \\
$\mathrm{a}^{*^{3}}$ & 20.71 & 18.08 & 20.11 & 3.397 \\
$\mathrm{~b}^{*^{4}}$ & 16.48 & 15.30 & 18.06 & 3.830 \\
$\mathrm{WBS}^{5}\left(\mathrm{~kg} / \mathrm{cm}^{2}\right)$ & 2.24 & 1.95 & 1.51 & 0.804 \\
Cooking loss (\%) $_{\text {Moisture (\%) }}$ & 27.94 & 25.71 & 24.49 & 3.909 \\
Protein (\%) & 73.56 & 73.25 & 73.55 & 0.739 \\
Fat (\%) & 20.94 & 21.55 & 21.10 & 0.508 \\
Ash (\%) & 2.37 & 2.21 & 2.27 & 0.688 \\
& 1.65 & 1.65 & 1.67 & 0.078 \\
\hline
\end{tabular}

${ }^{1}$ Standard error of means; ${ }^{2}$ L: Lightness; ${ }^{3}$ a: Redness; ${ }^{4}$ b: Yellowness

${ }^{5}$ WBS: Warner Bratzler Shear force

Ledward et al. (1986) reported that differences in meat colour may be due to variations in $\mathrm{pH}$ values. Several authors reported that a $\mathrm{pH}_{24}$ above 6.0 represented a meat quality problem because it causes a dark red colour (Bartoš et al., 1993; Kreikemeier et al., 1998; Mancini \& Hunt, 2005; Mounier et al., 2006) and increased variation in tenderness (Silva et al., 1999). In this study, the alternative dietary protein sources did not affect meat colour (Table 6), and showed results similar to those reported by Gatellier et al. (2005) in the Charolais breed. The replacement of soybean with faba bean or sweet lupin did not influence the tenderness and cooking loss of meat (Table 6), in agreement with Vicenti et al. (2009) and Girolami et al. (2007), who fed the same protein sources in a diet for Podolian bulls.

The FA profile of the $L I$ muscle is shown in Table 7. Diet did not affect the percentage values of saturated fatty acids (SFA). C16:0 was the most abundant SFA (28-29\%) in meat of the three groups, followed by C18:0 (13-15\%). These results are in general agreement with those reported by Vicenti et al. (2009) in young Podolian bulls. The MUFA concentration of meat did not differ among groups, similar to other studies that were carried out on lambs (Velasco et al., 2001; Lestingi et al., 2015) and beef cattle (Vicenti et al., 2009). The most abundant MUFA was C18:1 n-9 cis9 (oleic acid), at $42-43 \%$, and was not affected by dietary treatments. Lupin diet determined a lower percentage of C18:2n-6 (C18:2 n-6 cis9,12) compared with soybean $(P<0.05)$. In agreement with Vicenti et al. (2009) in Podolian cattle, the higher proportion of linoleic acid in meat may be due to the higher concentration of this fatty acid in the soybean diet compared with the lupin one.

Feeding sweet lupin diet led to a significant $(P<0.01)$ increase of the concentration of $\mathrm{C} 20: 3$ (dihomo$\mathrm{Y}$-linolenic acid) and C20:4n-6 (arachidonic acid) in comparison with both the faba bean and soybean groups. These two FAs are synthesized from linoleic acid by successive desaturation and elongation processes. Two desaturase enzymes, $\Delta 5$ desaturase and $\Delta 6$ desaturase, have been identified in PUFA formation pathways, while elongase 2 and 5 are also involved in long-chain PUFA synthesis (Cho et al., 1999a; 1999b). Tissue arachidonic acid pools originate from the diet and from hepatic and extrahepatic desaturation-elongation of dietary linoleic acid. In the liver in particular $\Delta 6$ desaturase activity seems to depend on nutritional, hormonal and metabolic factors, which were reviewed by Zhou \& Nilsson (2001). On the other hand, the sweet lupin diet reduced $(P<0.05)$ the concentration of DHA in comparison with faba bean. In all three groups, the concentration of this fatty acid was low. 
Table 7 Mean ( \pm SE) fatty acid composition (percentage of total FA methyl esters) of meat from the Longissimus lumborum muscle of Charolais heifers

\begin{tabular}{|c|c|c|c|c|}
\hline & \multicolumn{3}{|c|}{ Diets } & \multirow{2}{*}{ SEM } \\
\hline & Soybean & Faba bean & Sweet Lupin & \\
\hline Total fatty acids (g/100 g muscle) & 1.85 & 1.75 & 1.80 & 0.203 \\
\hline C12:0 & 0.06 & 0.08 & 0.08 & 0.021 \\
\hline C14:0 & 3.01 & 3.12 & 3.48 & 0.596 \\
\hline C16:0 & 29.21 & 28.87 & 29.86 & 1.801 \\
\hline C17:0 & 1.22 & 1.19 & 1.30 & 0.246 \\
\hline C18:0 & 15.02 & 13.22 & 14.26 & 2.117 \\
\hline C20:0 & 0.12 & 0.05 & 0.05 & 0.117 \\
\hline Total SFA ${ }^{2}$ & 48.64 & 46.53 & 49.03 & 2.833 \\
\hline C16:1 c9 & 3.40 & 3.68 & 3.71 & 0.744 \\
\hline C17:1 c10 & 0.82 & 0.86 & 0.81 & 0.236 \\
\hline C18:1 c9 & 42.73 & 43.36 & 42.01 & 2.648 \\
\hline C18:1 c7 & 1.43 & 1.56 & 1.55 & 0.188 \\
\hline Total MUFA ${ }^{3}$ & 48.29 & 49.46 & 48.08 & 2.905 \\
\hline C18:2 c9,12 (n-6) & $2.38^{a}$ & 2.31 & $2.11^{\mathrm{b}}$ & 0.363 \\
\hline C18:2 c9,t11 (n-6) & 0.13 & 0.14 & 0.16 & 0.038 \\
\hline C18:3 c6,9,12 (n-6) & 0.03 & 0.04 & 0.03 & 0.012 \\
\hline$C 20: 3$ c8,11,14 (n-6) & $0.06^{\mathrm{B}}$ & $0.07^{\mathrm{B}}$ & $0.09^{\mathrm{A}}$ & 0.015 \\
\hline $\mathrm{C} 20: 4 \mathrm{c} 5,8,11,14(\mathrm{n}-6)$ & $0.12^{\mathrm{B}}$ & $0.13^{\mathrm{B}}$ & $0.20^{A}$ & 0.049 \\
\hline Total $n-6^{4}$ & 2.72 & 2.69 & 2.59 & 0.246 \\
\hline C18:3 c9,12,15 (n-3) & 0.08 & 0.06 & 0.07 & 0.055 \\
\hline C20:3 c11,14,17 (n-3) & 0.08 & 0.07 & 0.08 & 0.029 \\
\hline C20:4 c5,8,t10,c14 (n-3) & 0.03 & 0.04 & 0.03 & 0.014 \\
\hline C20:5 c8,11,14,17 (n-3; EPA) & 0.13 & 0.13 & 0.12 & 0.045 \\
\hline C22:6 n-3 c7,10,13,16,19 (n-3; DHA) & 0.02 & 0.03 & 0.02 & 0.018 \\
\hline Total $n-3^{5}$ & 0.34 & 0.33 & 0.30 & 0.063 \\
\hline Total PUFA ${ }^{6}$ & 3.06 & 3.02 & 2.90 & 0.273 \\
\hline PUFA/SFA & 0.06 & 0.06 & 0.06 & 0.095 \\
\hline$n-6 / n-3$ & 8.00 & 8.15 & 8.35 & 1.68 \\
\hline Atherogenic index & 0.80 & 0.77 & 0.87 & 0.10 \\
\hline Thrombogenic index & 1.77 & 1.63 & 1.82 & 0.206 \\
\hline \multicolumn{5}{|c|}{ 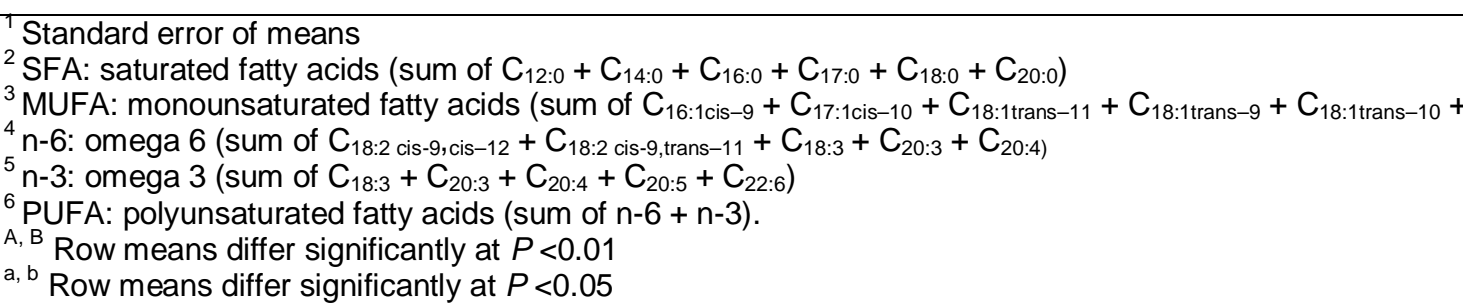 } \\
\hline
\end{tabular}

Considering the effects of dietary protein sources on the FA ratios that are important for human health, no statistical differences occurred among groups for either the PUFA/SFA or the n-6/n-3 ratios, in agreement with Vicenti et al. (2009). In a comparative study on 15 beef cattle breeds, meat from Charolais bulls showed a lower n-6/n-3 ratio in comparison with the current study. However, as reported by Enser et al. (1998) and Wood et al. (2008), the n-6/n-3 ratio may differ widely within breed, depending on the production system. 
According to Vicenti et al. (2009), the various protein sources did not affect the atherogenic and thrombogenic indices, which were similar among groups.

The data for blood parameters are reported in Table 8. In general, the dietary protein source had no effect on the parameters, which showed values that fell within the normal range for beef cattle, as reported by other authors (Bellmann et al., 2004; Grünwaldt et al., 2005; Ndlovu et al., 2007; Pavlik et al., 2010). However, feeding sweet lupin containing diet lowered $(P<0.05)$ the blood urea concentration in comparison with the soybean group.

Table 8 Mean ( \pm SE) blood parameters of Charolais heifers

\begin{tabular}{lcccc}
\hline & \multicolumn{3}{c}{ Diet } & \multirow{2}{*}{ SEM $^{\mathbf{1}}$} \\
\cline { 2 - 4 } & Soybean & Faba bean & Sweet Lupin & \\
\hline Total protein (g/dL) & 7.10 & 6.96 & 7.14 & 0.34 \\
Albumin (\%) & 45.67 & 45.12 & 43.36 & 3.97 \\
$\alpha 1$-globulin (\%) & 5.97 & 6.19 & 6.34 & 1.11 \\
$\alpha$ 2-globulin (\%) & 8.69 & 8.40 & 8.56 & 0.91 \\
$\beta 1$-globulin (\%) & 12.99 & 13.32 & 13.82 & 1.29 \\
$\beta 2$-globulin (\%) & 7.77 & 8.51 & 8.34 & 1.15 \\
$\gamma 1$-globulin (\%) & 18.83 & 18.45 & 19.54 & 3.99 \\
Urea (mg/dL) & $37.56^{\mathrm{a}}$ & 35.16 & $31.29^{\mathrm{b}}$ & 5.39 \\
Glucose (mg/dL) & 78.00 & 79.37 & 86.62 & 8.31 \\
NEFA ${ }^{2}(\mathrm{mEq} / \mathrm{L})$ & 0.13 & 0.10 & 0.09 & 0.08
\end{tabular}

\footnotetext{
1 Standard error of means; $a, b$ : row means with different superscripts differ significantly at $P<0.05$

${ }^{2}$ NEFA: Non esterified fatty acids
}

Blood urea levels reflect changes in protein metabolism (Hammond, 2006). Several authors have noted that its concentration depends on factors such as the amount of ingested proteins in the diet, their degradation in the rumen, the dietary composition of ingested amino acids and carbohydrate degradation in the rumen (Brown \& Adjei, 2001; Nazi et al., 2003; Thrall et al., 2004; Grünwaldt et al., 2005; Oulun, 2005). In the current experiment, the animals fed the soybean diet showed a higher feed intake, but a worse feed conversion ratio than those receiving the other protein sources. Masoero et al. (2005) reported that the protein fractions of soybean and faba bean are more degradable than those of lupin seed, therefore causing an increase in blood urea level as a consequence of protein degradation. The blood urea values in the current study were slightly higher than those reported by Bellmann et al. (2004) in the same breed. This difference may be due to the different ages of the bulls, which were younger ( 9 as opposed to 15 months) and on a longer feeding period than in the current study.

\section{Conclusion}

In conclusion, the results from the present study suggest that the use of faba bean and lupin seed in pelleted feeds for Charolais cattle represents a valid alternative to soybean meal. In fact, although the results in productive performance, carcass composition, meat quality and blood analysis were similar among the three groups, faba bean and sweet lupin represent a strategic choice from an agricultural and economic point of view since they are commonly cultivated in southern Italy.

\section{Authors' Contributions}

MR conceived and designed the study. MAC performed the experimental work, laboratory analysis, collaborated in the preparation of the manuscript and wrote the paper. AL collaborated in the preparation of the manuscript. ST carried out meat analysis. FG collaborated in animal management and in the collection of the productive performance data. GM conceived and designed the study. AMF performed blood analysis, was involved in the statistics and interpretation of the data and constructive revision of the manuscript, and helped with writing the paper.

\section{Conflict of Interest Declaration}

The authors declare that they have no competing interests. 


\section{References}

AOAC, 1995. Official methods of analysis, 16th edition. Association of Official Analytical Chemists, Inc., Arlington, Virginia, USA.

AOAC, 2004. Official methods of analysis, 18th edition. Association of Official Analytical Chemists, Inc., Arlington, Virginia, USA.

ASPA, 1996. Metodiche per la determinazione delle caratteristiche qualitative della carne (Procedures for meat quality evaluation). Scientific Association of Animal Production, Università di Perugia, Perugia, Italy (in Italian).

Atti, N. \& Mahouachi, M., 2009. Effects of feeding system and nitrogen source on lamb growth, meat characteristics and fatty acid composition. Meat Sci. 81, 344-348.

Bartoš, L., Franc, Č., Řehák, D. \& Štípková, M., 1993. A practical method to prevent dark-cutting (DFD) in beef. Meat Sci. 34, 275-282.

Bellmann, O., Wegner, J.C., Rehfeldt, F., Teuscher, F., Schneider, F., Voigt, J., Derno, M., Sauerwein, H., Weingärtner, J. \& Ender, K., 2004. Beef versus dairy cattle: A comparison of metabolically relevant hormones, enzymes, and metabolites. Livst. Sci. 89, 41-54.

Brown, W.F. \& Adjei, M.B., 2001. Urea and (or) feather meal supplementation for yearling steers grazing limpograss (Hemarthria altissima var. 'Floralta') pasture. J. Anim. Sci. 79, 3170-3176.

Cabaraux, J.F., Dufrasne, I., Istasse, L. \& Hornick, J.L., 2004. Effects of age on plasma metabolites and hormones in finishing Belgian Blue double-muscled cull females. Anim. Sci. 78, 229-235.

Calabrò, S., Cutrignelli, M.I., Gonzalez, O.J., Chiofalo, B., Grossi, M., Tudisco, R., Panetta, C. \& Infascelli, F., 2014. Meat quality of buffalo young bulls fed faba bean as protein source. Meat Sci. 96, 591-596.

Cho, H.P., Nakamura, M.T. \& Clarke, S.D., 1999a. Cloning, expression, and nutritional regulation of the mammalian Delta-6 desaturase. J. Biol. Chem. 274, 471-477.

Cho, H.P., Nakamura, M. \& Clarke, S.D., 1999b. Cloning, expression, and fatty acid regulation of the human delta-5 desaturase. J. Biol. Chem. 274, 37335-37339.

Christie, W.W., 1982. Lipid analysis-isolation, separation, identification and structural analysis of lipids. Pergamon, Oxford, pp. 270.

Cocca, C., Ragni, M., Dimatteo, S., Di Turi, L. \& Vicenti, A., 2005. Prestazioni produttive di vitelli podolici allevati con differenti regimi alimentari (Productive performances in Podolian young bulls fed alternative protein sources). Proceedings of the 4th World Italian Beef Cattle Congress, 29 April-1 May 2005, Gubbio (PG), Italy.

Crépon, K., Marget, P., Peyronnet, C., Carrouèe, B., Arese, P. \& Duc, G., 2010. Nutritional value of faba bean (Vicia faba L.) seeds for feed and food. Faba beans in sustainable agriculture. Field Crops Res. 115, 329-339.

Directive 98/58/EC. Legislative Decree n. 146, 26 March 2001, on Implementation of Directive 98/58/EC Concerning the Protection of Animals on Farms (available at the website https://eur-lex.europa.eu/legalcontent/EN/TXT/?uri=CELEX:31998L0058).

El Maadoudi E.H., 2006. Lupine seeds in diets of growing and fattening sheep. Recueil des Résumés des Communications du Premier Congrès National «Amélioration de la production agricole» Settat, 16-17 mars 2006, 63 (in French).

Enser, M., Hallett, K.G., Hewett, B., Fursey, G.A.J., Wood, J.D. \& Harrington, G., 1998. Fatty acid content and composition of UK beef and lamb muscle in relation to production system and implications for human nutrition. Meat Sci. 49, 329-341.

Facciolongo, A.M., Rubino, G., Zarrilli, A., Vicenti, A., Ragni, M. \& Toteda, F., 2014. Alternative protein sources in lamb feeding 1. Effects on productive performances, carcass characteristics and energy and protein metabolism. Progr. Nutr. 16, 105-115.

Folch, J., Lees, M. \& Sloan-Stanley, G.H., 1957. A simple method for the isolation and purification of total lipids from animal tissues. J. Biol. Chem. 226, 497-509.

Gatellier, P., Mercier, Y., Juin, H. \& Renerre, M., 2005. Effect of finishing mode (pasture- or mixed-diet) on lipid composition, colour stability and lipid oxidation in meat from Charolais cattle. Meat Sci. 69, 175-186.

Girolami, A., Marino, R., Sodo, A., Sabia, E., Braghieri, A. \& Pacelli, C., 2007. Impiego del favino nell'alimentazione dei vitelloni podolici (faba bean in feed for young Podolian bulls). Taurus Speciale 19, 83-92 (in Italian).

Grünwaldt, E.G., Guevara, J.C., Estevez, O.R., Vicente, A., Rousselle, H., Alcuten, N., Aguerregaray, D. \& Stasi, C.R., 2005. Biochemical and haematological measurements in beef cattle in Mendoza Plain rangelands (Argentina). Trop. Anim. Health Prod. 37, 527-540.

Hammond, A.C., 2006. Update on BUN and MUN as a guide for protein supplementation in cattle. US Department of Agriculture, Florida.

Immonen, K., \& Puolanne, E., 2000. Variation of residual glycogen-glucose concentration at ultimate pH values below 5.75. Meat Sci. 55, 279-283.

Immonen, K., Ruusunen, M., Hissa, K. \& Puolanne, E., 2000. Bovine muscle glycogen concentration in relation to finishing diet, slaughter and ultimate $\mathrm{pH}$. Meat Sci. 55, 25-31.

INRA, 1988. Alimentation des bovins, ovins et caprins. In: R. Jarrige, (ed.). Institut National de la Recherche Agronomique, INRA, Paris.

INRA, 1989. Ruminant nutrition, recommended allowances and feed tables. In: R. Jarrige (ed.). Institut National de la Recherche Agronomique, INRA, Paris.

Kannan, G., Chawan, C.B., Kouakou, B. \& Gelaye, B., 2002. Influence of packaging method and storage time on shear value and mechanical strength of intramuscular connective tissue of chevon. J. Anim. Sci. 80, 2383-2389.

Kreikemeier, K.K., Unruh, J.A. \& Eck, T.P., 1998. Factors affecting the occurrence of dark-cutting beef and selected carcass traits in finished beef cattle. J. Anim. Sci. 76, 388-395. 
Ledward, D.D., Dickinson, R.F., Powell, V.H. \& Shorthose, W.R., 1986. The colour and colour stability of beef Longissimus dorsi and Semimembranosus muscle after effective electrical stimulation. Meat Sci. 16, $245-265$.

Lestingi, A., Toteda, F., Vicenti, A., De Marzo, D. \& Facciolongo, A.M., 2015. The use of faba bean and sweet lupin seeds alone or in combination for growing lambs. 1. Effects on growth performance, carcass traits, and blood parameters. Pakistan J. Zool. 47, 989-996.

Lestingi, A., Facciolongo, A.M., Caputi Jambrenghi, A.M., Ragni, M. \& Toteda, F., 2016. The use of peas and sweet lupin seeds alone or in association for fattening lambs: Effects on performance, blood parameters and meat quality. Small Rum. Res. 143, 15-23.

Mach, N., Bach, A., Velarde, A. \& Devant, M., 2008. Association between animal, transportation, slaughterhouse practices, and meat $\mathrm{pH}$ in beef. Meat Sci. 78, 232-238.

Magalhãesa, S.C.Q., Fernandes, F., Cabrita, A.R.J., Fonseca, A.J.M., Valentão, P. \& Andrade, P.B., 2017. Alkaloids in the valorization of European Lupinus spp. seeds crop. Ind. Crops Prod. 95, 286-295.

Mancini, R.A. \& Hunt, M.C., 2005. Current research in meat color. Meat Sci. 71, 100-121.

Masoero, F., Pumineno, A.M. \& Rossi, F., 2005. Effect of extrusion, expansion and toasting on the nutritional value of peas, faba beans and lupins. Ital. J. Anim. Sci. 4, 177-189.

Mounier, L., Dubroeucq, H., Andanson, S. \& Veissier, I., 2006. Variations in meat pH of beef bulls in relation to conditions of transfer to slaughter and previous history of the animals. J. Anim. Sci. 84, 1567-1576.

Nazi, S., Saeb, M., Rowghani, E. \& Kaveh, K., 2003. The influences of thermal stress on serum biochemical parameters of Iranian fat-tailed sheep and their correlation with tri-iodothryonine (T3), thyroxine (T4) and cortisol concentrations. Comp. Clin. Pathol. 12, 135-139.

Ndlovu, T., Chimonyo, M., Okoh, A.I., Muchenje, V., Dzama, K. \& Raats, J.G., 2007. Assessing the nutritional status of beef cattle: Current practices and future prospects. Afr. J. Biotech. 6, 2727-2734.

Oulun, Y., 2005. Variation in the blood chemical constituents of reindeer, significance of season, nutrition and other extrinsic and intrinsic factors. Acta Universitatis Ouluensis, Scientiae Rerum Naturalium, A440.

Pavlík, A., Jelinek, P., Matejicek, M. \& Illek, J., 2010. Blood plasma metabolic profile of Aberdeen Angus bulls during postnatal ontogenesis. Acta Vet. BRNO 79, 419-429.

Prandini, A., Morlacchini, M., Moschini, M., Fusconi, G., Masoero, F. \& Piva, G., 2005. Raw and extruded pea (Pisum sativum) and lupin (Lupinus albus var. Multitalia) seed as protein sources in weaned piglets' diets: Effect on growth rate and blood parameters. Ital. J. Anim. Sci. 4, 385-394.

Ragni, M., Vicenti, A., Dimatteo, S., Melodia, L., Marsico, G. \& Vonghia, G., 2000. Fonti proteiche alternative nell'alimentazione degli agnelli: 1. Effetto del lupino dolce sulle performance produttive (Alternative protein sources in lamb feeding: 1 . Effect of sweet lupin on productive performances). SISVet (Società Italiana di Scienze Veterinarie) Annual Meeting Selected Abstracts 2, 433-434 (In Italian).

Ragni, M., Toteda, F., Vicenti, A., Facciolongo, A.M. \& Melodia, L., 2007a. Raw and extruded field beans (Vicia faba var. minor) as alternative protein sources in heavy lamb diets. Ital. J. Anim. Sci. 6, 345.

Rotger, A., Ferret, A., Calsamiglia, S. \& Manteca, S., 2006. In situ degradability of seven plant protein supplements in heifers fed high concentrate diets with different forage to concentrate ratio. Anim. Feed Sci. Technol. 125, 73-87.

SAS, 2000. Statistical Analysis System user's guide. SAS Institute Inc., Raleigh, North Carolina, USA.

Scerra, M., Caparra, P., Foti, F., Cilione, C., Zappia, G., Motta, C. \& Scerra, V., 2011. Intramuscular fatty acid composition of lambs fed diets containing alternative protein sources. Meat Sci. 87, 220-233.

Šicklep, M. \& Čandek-Potokar, M., 2007. Pork color measurement as affected by bloom time and measurement location. J. Muscle Foods 18, 78-87.

Silva, J.A., Patarata, L. \& Martins, C., 1999. Influence of ultimate pH on bovine meat tenderness during ageing. Meat Sci. $52,453-459$.

SINAB, 2017 Sistema d'Informazione Nazionale sull'Agricoltura Biologica (National Information System on Organic Agriculture), avaliable at http://www.sinab.it/

Tarricone, S., Marsico, G., Ragni, M., Forcelli, M.G., Pinto, F., Vicenti, A. \& Rasulo, A., 2009. Chemical and acidic characteristics of meat of Podolian bulls slaughtered at different ages. Ital. J. Anim. Sci. 8, 575.

Thrall, M.A., Baker, C., Campbell, T.W., Denicola, D., Fettman, M.J., Lassen, E.D., Rebar, A. \& Weiser, G., 2004. Veterinary haematology and clinical chemistry. Eds. Lippincott Williams \& Wilkins, Philadelphia.

Tufarelli, V., Naz, S., Khan, R.U., Mazzei, D., Introna, M. \& Laudadio, V., 2012a. Milk quality, manufacturing properties and blood biochemical profile from dairy cows fed peas (Pisum sativum L.) as dietary protein supplement. Archiv Tierzucht 55: 132-139.

Tufarelli, V., Khan, R.U. \& Laudadio, V., 2012b. Evaluating the suitability of field beans as a substitute for soybean meal in early-lactating dairy cows: Production and metabolic responses. Anim. Sci. J. 83:136-140.

Ulbricht, T.L. \& Southgate, D.A.T., 1991. Coronary heart disease: Seven dietary factors. The Lancet 338, 985-922.

Van Saun, R., 2000. Blood profiles as indicators of nutritional status. Proc. 18th Ann. West. Can. Dairy Sem., Red Deer, Alberta, Canada, 1-6.

Velasco, S., Cañeque, V., Pérez, C., Lauzurica, S., Díaz, M.T., Huidobro, F., Manzanares, C. \& González, J., 2001. Fatty acid composition of adipose depots of suckling lambs raised under different production systems. Meat Sci. 59, 325-333.

Vicenti, A., Toteda, F., Di Turi, L., Cocca, C., Perrucci, M., Melodia, L. \& Ragni, M., 2009. Use of sweet lupin (Lupinus albus L. var. Multitalia) in feeding for Podolian young bulls and influence on productive performances and meat quality traits. Meat Sci. 82, 247-251.

Volpelli, L.A., Comellini, M., Masoero, F., Moschini, M., Lo Fiego, D.P. \& Scipioni, R., 2010. Faba beans (Vicia faba) in dairy cow diet: Effect on milk production and quality. Ital. J. Anim. Sci., 9:1, e27, 138-144. 
Volpelli, L.A., Comellini, M., Gozzi, M., Masoero, F. \& Moschini, M., 2012. Pea (Pisum sativum) and faba beans (Vicia faba) in dairy cow diet: Effect on milk production and quality. Ital. J. Anim. Sci. 11:2, e40, 217-222.

Wood, J.D., Enser, M., Fisher, A.V., Nute, G.R., Sheard, P.R., Richardson, R.I., Hughes, S.I. \& Whittington, F.M., 2008. Fat deposition, fatty acid composition and meat quality: A review. Meat Sci. 78, 343-358.

Yu, P., Goelema, J.O., Leury, B.J., Tamminga, S. \& Egan, A.R., 2002. An analysis of the nutritive value of heat processed legume seeds for animal production using the DVE/OEB model: A review. Anim. Feed Sci. Technol. 99, 141-176.

Zander, P., Amjath-Babu T.S., Preissel, S., Reckling, M., Bues, A., Schläfke, N., Kuhlman, T., Bachinger, J., Uthes, S., Stoddard, F. et al., 2016. Grain legume decline and potential recovery in European agriculture: A review. Agron. Sustain. Dev. 36, 26-46.

Zhou, L. \& Nilsson, A., 2001. Sources of eicosanoid precursor fatty acid pools in tissues. J. Lipid. Res. 42, $1521-1542$. 